\title{
The evaluation of implementing the European Union's regulations regarding non-financial information in Poland
}

\author{
MSc. Ewelina Papaj-Wlisłocka \\ University of Economics in Katowice \\ Department of Accounting
}

\begin{abstract}
The main aim of this paper is to analyse and evaluate how the regulations of Directive 2014/95/EU in terms of non-financial information disclosures have been implemented to the Polish Act of Accounting. According to EU's regulations, each country has to enforce nonfinancial information disclosures and 2017 was the first year in which the largest Polish companies were required to disclose non-financial information in their financial statements. This obligation appeared to be a big challenge for those entities. What is more, the legislator gave the companies a certain level of freedom on several issues, e.g. they can choose the form of presentation.

The theoretical part of this article aims to emphasise the major impact which the European Union's regulations had on the Polish accounting system. The paper also features an empirical part, based on the material from the conference held by the Polish Ministry of Finance in March 2019. It aimed to present good practices and some first experiences of Polish companies related to the presentation of non-financial information. The article will also be an attempt to discuss the matter of supervising the content of disclosed non-financial information. The research method applied in the article will be a critical analysis of the literature, legal acts, as well as an analysis of the research provided by the Polish Ministry of Finance.
\end{abstract}

Keywords: business reporting, Directive 2014/95/EU; financial statements; modern accounting; non-financial disclosures. 


\title{
International Conference on Advanced Research in MANAGEMENT, ECONOMICS AND ACCOUNTING
}

\author{
5-7 September, 2019
}

\author{
Barcelona, spain
}

$\mathrm{M}_{\mathrm{E}} \mathrm{A}$

MANAGEMENT, ECONOMICS \& ACCOUNTING CONFERENCE

\section{Introduction}

Rapid changes in business environment as well as growing needs of financial reports' recipients caused development in the area of financial reporting (Orens \& Laybaert, 2007). Among many factors that determine business success, the value of information connected to environmental and social issues is becoming increasingly important. What is more, literature indicates that nowadays economy is based on knowledge, sustainable development and socially responsible business (Shapiro, 2007). These values cannot be presented using traditional reports. Non-financial information has become a response to new challenges. Investors and other recipients of published reports pay attention to the quality of data presented (Lundholm et al., 2014). From the investor's point of view, clear data presentation is a crucial factor, which can also reduce the time spent on searching for information. The above postulates are particularly important in the case of non-financial data, which are characterised by relatively high flexibility of disclosure. The article will present legal regulations related to disclosing non-financial information. The paper is also enriched with an empirical part, featuring an analysis of the report "Reporting of extended non-financial information in 2017 - first experiences and good practices" by the Polish Ministry of Finance, which summarises the first year of reporting obligations.

\subsection{Non-financial information in accounting}

Accounting - also known as "the language of business" - had to adopt to challenges posed by modern economies. Disclosure of non-financial information has become a response to the modern business environment. The need to introduce development in traditional accounting system has also been noticed by the European Union's Authorities. Directive 2014/95/EU of the European Parliament and of the Council of $22^{\text {nd }}$ October 2014 introduce an obligation of non-financial information disclosure by certain large companies and groups. An answer to the Directive 2014/95/EU was the amendment to the Polish Act of Accounting (the basic legal act regulating the accounting system in Poland). Article $49 \mathrm{~b}$ in the amended Act of Accounting, introduced criteria based on employment, total balance sheet assets as well as the net revenue from the sale of goods and materials. Companies which in the financial year for which the financial statement is made for, and in the previous year, exceeded the following amounts:

- 500 employees - in terms of annual average employment expressed in full time equivalents and

- 85,000,000 PLN - in terms of the total balance sheet assets at the end of the accounting year or $17,000,000$ PLN - in the net revenue from the sale of goods and materials in the financial year

are obliged to disclose non-financial information as a part of financial statement.

Non-financial information disclosures are presented in Figure 1. 


\section{International Conference on Advanced Research in MANAGEMENT, ECONOMICS AND ACCOUNTING}

\section{5-7 September, 2019}

\section{Barcelona, spain}

Figure 1: The scope of non-financial information disclosures

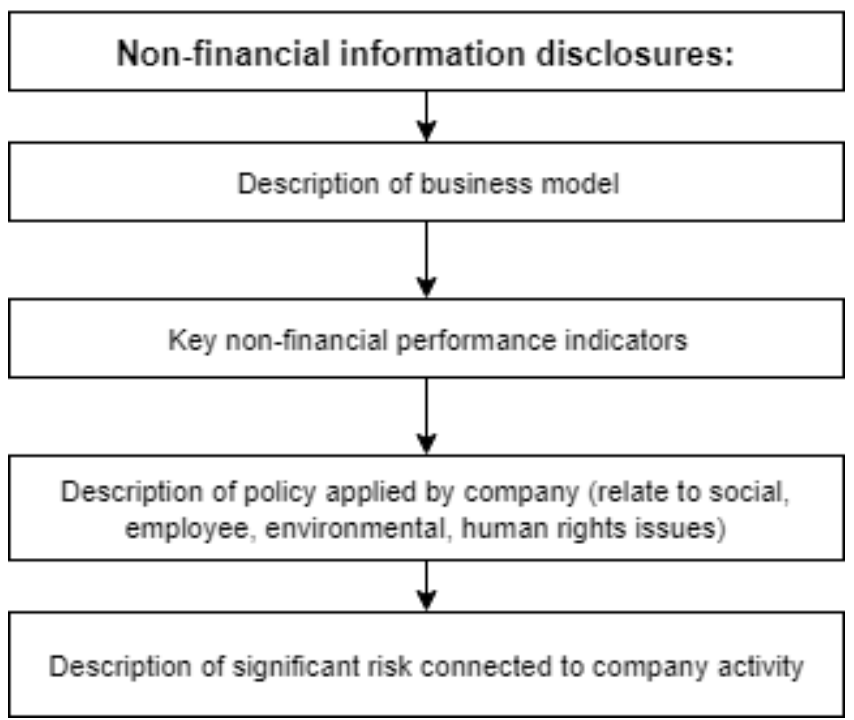

Source: Own elaboration according to the Polish Act of Accounting.

One of the business model's definitions constitutes that it concerns the philosophy adopted by the company. According to this philosophy, company achieves a competitive advantage that may contribute to a success in global market. Information about business model is also called "sensitive data". It is also worth mentioning that business model information disclosures can be unfavorable and harmful for the company, especially taking into consideration the competitors activities. In order to protect companies and in the same time provide reliable information to financial statement recipients, the legislator used the word "concise" to describe how the business model should be presented.

Another disclosure includes key non-financial performance indicators. These are indicators that assess the degree of implementation of strategic goals and plans by the company. The usage of KPIs (key performance indicators) enables building a results-oriented organization, which is an important "added value" resulting from non-financial information disclosures (Arvidsson, 2011). The KPIs can be divided into many categories covering various aspects of company's activities such as:

a) influence on natural environment (examples of indicators: carbon dioxide emission or number of possessed environmental certificates);

b) relations with local community and employees (examples of indicators: intellectual capital, employee satisfaction, employment turnover)

c) customer relations (examples of indicators: customer satisfaction, newly acquired customers).

The choice of the KPIs depends on an individual decision of each company. Bearing in mind the information needs of non-financial information recipients, it is important that the number of indicators is not too extensive. Modern reporting requires to strike a balance, especially considering the problem of information overload (Gamerschlag et. al., 2011). 


\title{
International Conference on Advanced Research in MANAGEMENT, ECONOMICS AND ACCOUNTING
}

\section{5-7 September, 2019}

\author{
Barcelona, spain
}

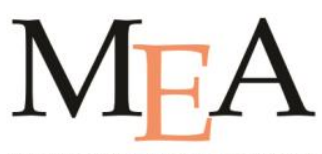

MANAGEMENT, ECONOMICS \& ACCOUNTING CONFERENCE

One more aspect of non-financial information disclosures is description of policy applied by company. The indicated policies relate to such issues as: social, employee and environmental relations,human rights issues and counteracting corruption and bribery. Non-financial information in such areas may relate to:

a) company's influence on the natural environment,

b) employment policy,

c) organisation and functioning of internal control,

d) cooperation with local communities,

e) diversity policy (Papaj-Wlisłocka \& Strojek-Filus, 2019).

For those disclosures, there is no exhaustive list of information that should be included in report. This can be seen as further evidence that the scope of disclosure of non-financial information depends on an individual choice of each company. That is why ethical attitude plays such a significant role.

Another important disclosure is the issue of risk. Risk is inseparably bound to the decisionmaking process in various types of human activity (Renn, 1998). Description of significant risks is an important part of non-financial information disclosures. One should also pay attention that a very important issue is to inform financial statements' recipients about risk management as well as risk mitigation process.

European Union Regulation introduced three areas, where the Member States have flexibility in terms of solutions employed:

a) in exceptional cases, a permission to omit information regarding expected events or subjects of negotiation, if their disclosure would have harmful effect on the situation of a unit,

b) permission to present information in a form of a separate report,

c) voluntary verification of a non-financial report. (Directive 2014/95/EU of the European Parliament and of the Council of 22 October 2014).

The obligation for the largest companies to disclose non-financial information has been introduced starting from the year 2017.

\section{Methods}

Disclosure of non-financial information was an undoubted challenge for Polish companies. Despite the fact that many companies had previously prepared CSR (Corporate Social Responsibility) reports on a voluntary basis, the first year of legal obligation turned out to be a big challenge. In March 2019, Polish Ministry of Finance has organized a conference devoted to assessment of the first year of non-financial information disclosure obligation among Polish companies. This event also gave the opportunity to distinguish the examples of good practices that have been implemented by the reporting companies. "Reporting of extended non-financial information in 2017 - first experiences and good practices" prepared by 21 independent experts appointed by Polish Ministry of Finance was published during the conference. Research sample consists of 123 reports published by the biggest Polish companies in 2017. The experts also completed the non-financial report evaluation cards, which formed the basis for subsequent analysis and evaluation. Analysis of the data from "Reporting of extended non-financial information in 2017 - first experiences and good 


\section{International Conference on Advanced Research in MANAGEMENT, ECONOMICS AND ACCOUNTING}

\section{5-7 September, 2019}

$\mathrm{M}_{\mathrm{E}} \mathrm{A}$

MANAGEMENT, ECONOMICS \& ACCOUNTING CONFERENCE

practices" provides grounds for evaluating the implementation of the European Union's regulations regarding non-financial information in Poland.

\section{Results and Discussion}

The first issue that was examined was the form of presenting the non-financial information. As it has already been mentioned, legal regulations have left companies some choice in this area. According to the amended Act of Accounting, companies may disclose non-financial information either in the form of a statement on non-financial information (but within the management report) or in a separate report covering non-financial information. Figure 2 shows which form of presentation is more popular among Polish Companies.

Figure 2: Form of non-financial information presentation

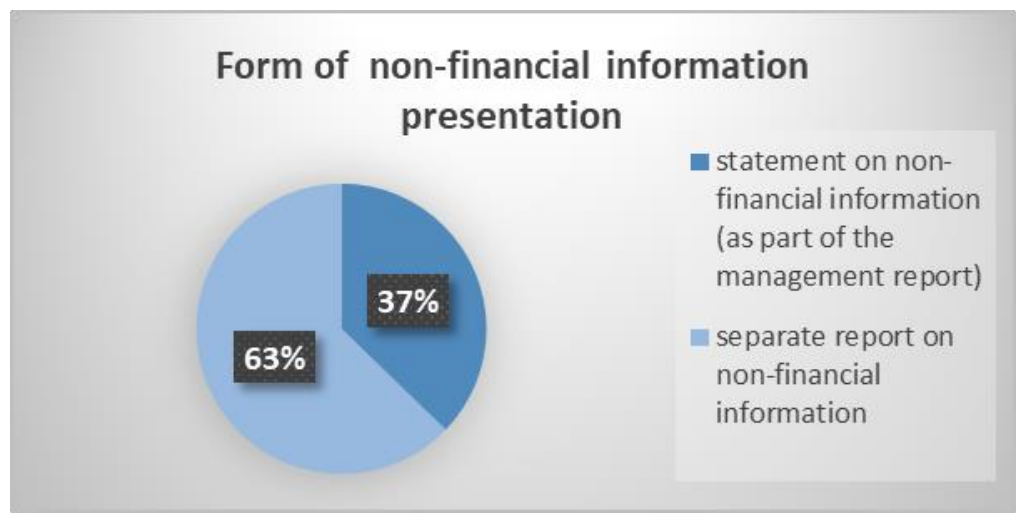

Source: Own elaboration according to "Reporting of extended non-financial information in 2017 - first experiences and good practices"

As it has been presented above, more Polish companies decided to prepare a separate report on non-financial information. The experts who conducted the research underlined, that many companies demonstrated certain issues with the terminology. Companies mistakenly interchanged the terms "statement on non-financial information" and "report on non-financial information", while they are not the same. Of course, it may seem not to be a significant error, but in order to comply with the Act of Accounting, companies should use the correct terminology.

Another area, in relation to which companies have freedom of choice, was voluntary verification of the non-financial report. According to the Act of Accounting, companies are not required to audit their report on non-financial information or statement on non-financial information but they can do it on a voluntary basis. The figure 3 shows whether the companies have verified the report or have used the exemption in this area. The vast majority of the surveyed companies did not carry out the verification. Only $8 \%$ of companies voluntarily verified their non-financial information report. 


\section{International Conference on Advanced Research in MANAGEMENT, ECONOMICS AND ACCOUNTING}

Figure 3: Voluntary verification of a non-financial information report

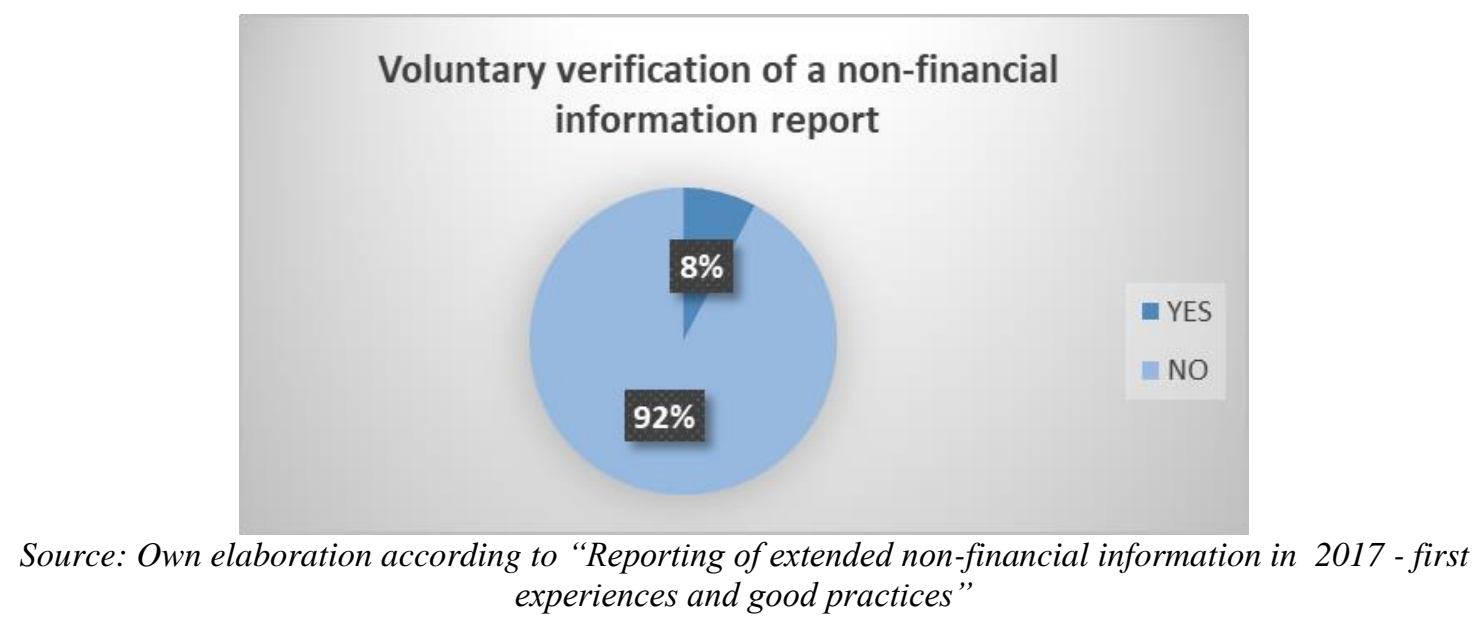

Verification of non-financial information has both supporters and opponents. There is no doubt that in the era of "information overload" report verification might ensure high quality and reliability of the presented content. This verification has been carried out for years in traditional financial statements. The question arises if is it possible to verify a non-financial information report. It should be noted that non-financial information disclosures are very different from traditional financial data. Non-financial data is of a holistic nature. It means that they contain information from various different areas, such as: corporate social responsibility, environmental issues, relations with employees etc. Verification of reports is therefore very difficult because it requires expert knowledge from many different fields of knowledge (Irwin \& McGill, 2018). Taking into account the growing importance of nonfinancial information disclosures, it will be necessary to train specialists in this field, as well as in the area of their verification. The individual, unique nature of non-financial data and flexibility in terms of their disclosure makes that company ethical attitude has a great impact on their credibility (Nielsen \& Thomsen, 2007). According to the literature of the subject, an important role here can be played by an internal audit (Murphy \& Hogan, 2016).

The last area with a large degree of flexibility in non-financial information disclosures was the permission to omit information regarding expected events or subjects of negotiation, if their disclosure would have harmful effect on the situation of a unit. In the analysis, none of the surveyed companies used this opportunity.

The next step of analysis was an assessment of the quality and transparency of non-financial information as well as its intelligibility. The result of assessment of the quality and transparency is shown on figure 4. 


\title{
International Conference on Advanced Research in MANAGEMENT, ECONOMICS AND ACCOUNTING
}

\author{
5-7 September, 2019
}

Barcelona, spain

$\mathrm{M}_{\mathrm{E}} \mathrm{A}$

MANAGEMENT, ECONOMICS

\& ACCOUNTING CONFERENCE

Figure 4: Assessment of the quality and transparency of non-financial information

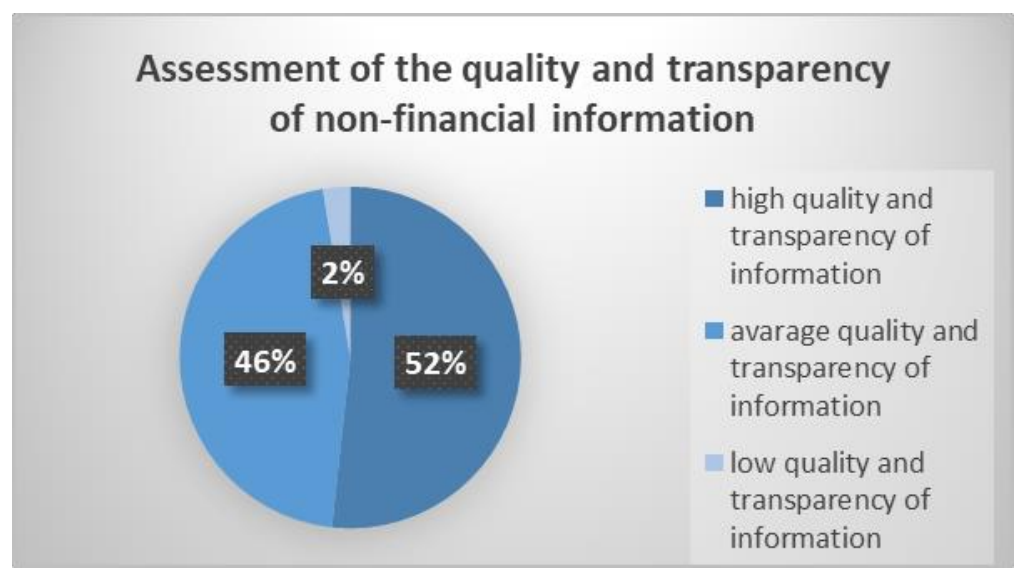

Source: Own elaboration according to "Reporting of extended non-financial information in 2017-first experiences and good practices"

As a part of the study, experts assessed the existence of all elements indicated by the Act of Accounting (description of business model, key non-financial performance indicators etc.) as well as the ease of finding them. Then they awarded points on a scale from 0 to 5 , where 5 was the highest score and 0 the lowest. If non-financial information was rated in the range between 5-4 points it meant high quality and transparency of information, consequently 3-2 points meant average quality and transparency of information and 1-0 points should be interpreted as low quality and transparency of information. Following figure 4, one should pay attention that there is a relatively small difference between the number of reports of high and average quality and transparency of information. What is more, the number of reports with high quality and transparency of information only slightly exceeds $50 \%$. On the other hand, only $2 \%$ of reports represent low quality and transparency of information, which is an undeniably positive observation.

A crucial factor in the process of non-financial information assessment is its intelligibility. This is a particularly important feature affecting the usefulness of information. Example of positive practice that has been noticed in Polish companies is the usage of "industry dictionaries". Their purpose is to explain specialistic words and phrases that may not be understood by all recipients. Industry dictionaries are particularly widespread among companies from fuel and energy, construction and IT industries. It should also be underlined that non-financial information, unlike traditional financial information, is directed to a wider group of users. That is why companies make every effort to increase their "user-friendly image". The above arguments also affect the results of research, presented in figure 5. 


\title{
International Conference on Advanced Research in MANAGEMENT, ECONOMICS AND ACCOUNTING
}

\author{
5-7 September, 2019
}

Barcelona, spain

$\mathrm{MEA}$

MANAGEMENT, ECONOMICS \& ACCOUNTING CONFERENCE

Figure 5: Assessment of intelligibility of non-financial information

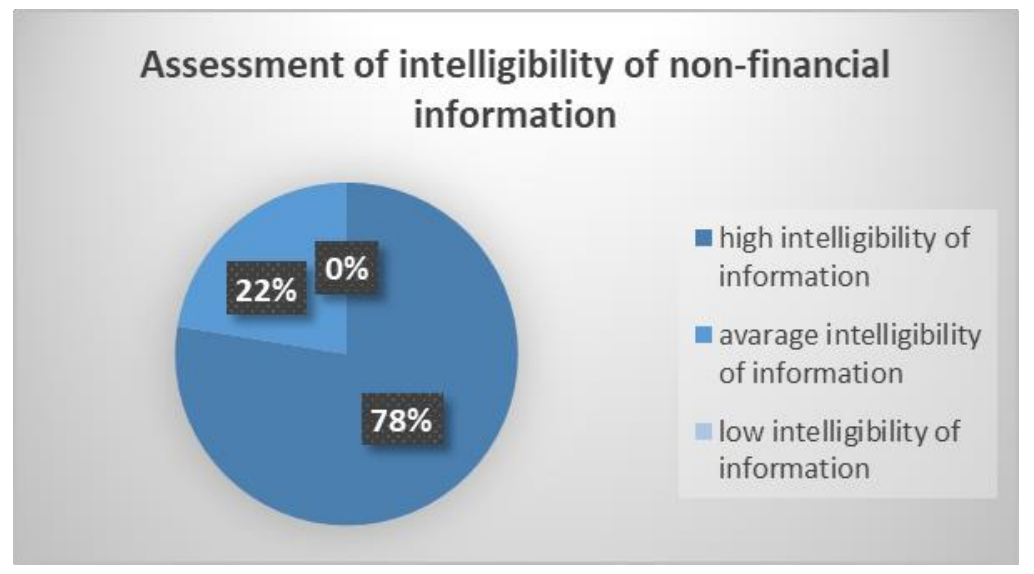

Source: Own elaboration according to "Reporting of extended non-financial information in 2017-first experiences and good practices"

The scoring method was the same as in the case of the assessment of the quality and transparency of non-financial information. However, the results are definitely more satisfactory.

A vast majority of reports represent high intelligibility of non-financial information. $22 \%$ represent an average intelligibility of information. Interestingly, the intelligibility was not rated as low in any report. It is another positive observation. Among the analyses of individual types of disclosures, most reservations concerned risk related issues. Experts underlined that companies did not make enough effort in this area of disclosures. Although they identify basic risk, there is a shortage of data concerning risk management and mitigation. This is surely an area improvement in the future.

\section{Conclusions}

The observation of the last years of business activities shows changes in the direction and awareness of financial statements' recipients. Traditional non-financial information is becoming insufficient (Beattie et. al., 2004). The crucial factors of market success such as relations with social community or impact on the environment cannot be presented in a traditional financial statement. It has become necessary to develop a disclosure concept that complements and introduces "added value" to traditional financial information. The need for changes has been noticed by the European Union Authorities. Directive 2014/95/EU introduced the obligation to disclose non-financial information for the biggest companies. The reporting obligation began in the year 2017. Although a large number of companies published non-financial information on a voluntary basis (before the Directive 2014/95/EU) 


\title{
International Conference on Advanced Research in MANAGEMENT, ECONOMICS AND ACCOUNTING
}

\section{5-7 September, 2019}

\author{
Barcelona, spain
}

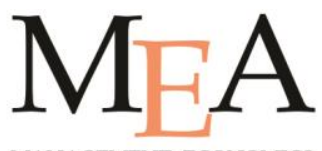

MANAGEMENT, ECONOMICS \& ACCOUNTING CONFERENCE

the first year of the statutory obligation was a challenge. The Polish Ministry of Finance has decided to organise in March 2019 a conference summarising the first year of mandatory disclosure of non-financial information. Its purpose was to evaluate the first year of reporting, underline the areas for improvement and identify good practices. The analysis of the presented research indicates that companies have in general correctly fulfilled their statutory obligation. However, it was pointed out that in many cases the problem was the correctness of the terminology usage (figure 2). The vast majority of companies has not decided to verify the reports, thus exercising their right to choose whether or not to do so. As far as assessment of quality and transparency of information is concerned, one should pay attention that in case of $52 \%$ of reports the quality of information was described as high and for $46 \%$ as average. It is also worth mentioning that high intelligibility of information was observed among $78 \%$ of the reports, which is a very positive result. It is also an evidence that modern accounting makes every effort to make the reports more reader-friendly. An area that should be improved is the issue of risk and risk management and mitigation. This can form a basis for further scientific work.

\section{References}

[1] Shapiro, C. (2007), Potega informacji. Strategiczny przewodnik po gospodarce sieciowej, Wydawnictwo Helion, Gliwice.

[2] Arvidsson, S., (2011), "Disclosure of non-financial information in the annual report- a management team perspective", Journal of Intellectual Capital, Vol. 12, Issue 2, pp. 278280.

[3]Beattie,V., McInnes,B., Fearnley, S., (2004),“A methodology for analysing and evaluating narratives in annual reports: a comprehensive descriptive profile and metrics for disclosure quality attributes”, Accounting Forum, Vol.28, pp. 205-215.

[4] Gamerschlag, R., Möller, K., and Verbeeten, F.,(2011), "Determinants of voluntary CSR disclosure: empirical evidence from Germany", Review of Managerial Science, Vol. 5, Issue 2-3, pp.233-262.

[5] Irwin, R., McGill, A. (2018), "Enhancing the credibility of non-financial information, the investor perspective", WBCSD \& Gordon and Betty Moore Foundation Report, pp. 6-15.

[6] Lundholm, J.T., Rogo, R., Zhang, L.J. (2014). "Restoring the tower of Babel: how foreign firms communicate with US investors", The Accounting Review, Vol. 89 No. 4, pp. 14531485 .

[7] Murphy, L., Hogan, R., (2016), "Financial reporting of nonfinancial information: the role of the auditor", Corporate Accounting \& Finance, November-December 2016,pp. 43-47.

[8] Nielsen, A.E., Thomsen,Ch., (2007), "Reporting CSR - what and how to say it"?, Corporate Communications An International Journal, Vol. 12, Issue 1, pp. 25-40.

[9] Orens, R., Lybaert, N., (2007), "Disclosures of non-financial information: relevant to financial analysts", Review of Business and Economic Literature, Vol. 58, Issue 04, pp.375405. 


\section{International Conference on Advanced Research in MANAGEMENT, ECONOMICS AND ACCOUNTING}

\section{5-7 September, 2019}

$\mathrm{M} \mathrm{EA}$

MANAGEMENT, ECONOMICS \& ACCOUNTING CONFERENCE

[10] Papaj-Wlisłocka, E., Strojek-Filus, M., (2019),"'Forward-looking information disclosure as a risk factor in accounting - the case of Poland", Multiple perspectives in risk and risk management. ERRN 8th European Risk Conference 2018, red. Philip Linsley, Philip Shrives, Monika Wieczorek-Kosmala, Springer Proceedings in Business and Economics, pp.125-141. [11] Renn, O., (1998), "Three decades of risk research: accomplishments and new challenges", Journal of Risk Research, Vol.1, Issue 1, pp. 49-71.

[12] Directive 2014/95/EU of the European Parliament and of the Council of 22 October 2014 amending Directive 2013/34/EU as regards disclosure of non-financial and diversity information by certain large undertakings and groups, OJ.EU from 15 November 2014

[13] Reporting of extended non-financial information in 2017-first experiences and good practices

Available: https://www.gov.pl/documents/1079560/1080340/Raport_MF.PDF/1b41abe7a7db-60a8-4641-cbbb0fb35764

[14] The Act of 29 September 1994 on Accounting (Polish Act of Accounting), Available:http://prawo.sejm.gov.pl/isap.nsf/download.xsp/WDU20180000395/O/D20180395. pdf 